\title{
The effect of hatchery waste meal in ration on nutrient retention and performances of laying quails
}

\author{
R. Indreswari and A. Ratriyanto* \\ Department of Animal Science, Faculty of Agriculture, Universitas Sebelas Maret, \\ Jl. Ir. Sutami 36A, Surakarta 57126 - Indonesia \\ *Corresponding E-mail: ratriyanto@staff.uns.ac.id
}

Received October 29, 2017; Accepted February 03, 2018

\begin{abstract}
ABSTRAK
Penelitian ini bertujuan mengkaji pengaruh penggunaan tepung limbah penetasan (TLP) keseluruhan dan tanpa kerabang terhadap retensi nutrien dan performa puyuh. Sebanyak 500 ekor puyuh betina (Coturnix coturnix japonica) berumur 30 hari dengan rata-rata bobot badan $94,75 \pm 4,17 \mathrm{~g}$ dikelompokkan ke dalam lima perlakuan pakan dengan lima ulangan, masing-masing ulangan berisi 20 ekor puyuh. Kelima pakan perlakuan terdiri dari Kontrol $=$ pakan basal, Keseluruhan $4 \%=96 \%$ pakan basal $+4 \%$ TLP keseluruhan, Keseluruhan $8 \%=92 \%$ pakan basal $+8 \%$ TLP keseluruhan, Tanpa Kerabang 4\% $=96 \%$ pakan basal $+4 \%$ TLP tanpa kerabang, dan Tanpa Kerabang $8 \%=92 \%$ pakan basal $+8 \%$ TLP tanpa kerabang. Data dianalisis menggunakan analisis variansi dan jika terdapat pengaruh perlakuan maka dilanjutkan dengan uji Duncan. Pemberian TLP meningkatkan retensi lemak, energi termetabolis semu serta konsumsi dan retensi kalsium $(\mathrm{P}<0,05)$. Pemberian TLP keseluruhan dan tanpa kerabang sampai $8 \%$ meningkatkan performa puyuh $(\mathrm{P}<0,05)$. Pemberian TLP juga meningkatkan bobot yolk dan albumen $(\mathrm{P}<0,05)$ yang diikuti penurunan indeks yolk dan albumen $(\mathrm{P}<0,05)$. Kesimpulan dari penelitian ini adalah pemberian TLP meningkatkan retensi nutrien dan performa puyuh.

Kata kunci: performa, puyuh, retensi nutrien, tepung limbah penetasan
\end{abstract}

\begin{abstract}
The objective of this study was to investigate the effect of hatchery waste meal (HWM) as a whole or without shell (shell-less) in the diet on nutrient retention and performance of quails. The study used 500 female quails (Coturnix coturnix japonica) aged 30 days with an average initial body weight of $94.75 \pm 4.17$ gr. The quails were randomly allocated to five dietary treatments in a completely randomized design with 5 replicates of 20 quails. The dietary treatments were: Control $=$ basal diet, Whole $4 \%=96 \%$ basal diet $+4 \%$ whole HWM, Whole $8 \%=92 \%$ basal diet $+8 \%$ whole HWM, Shellless HWM 4\% $=96 \%$ basal diet $+4 \%$ of shell-less HWM, Shell-less HWM $8 \%=92 \%$ basal diet $+8 \%$ of shell-less HWM. The data were subjected to analysis of variance, when the treatments indicated significant effect it was continued with Duncan's Multiple Range Test. Quails fed HWM up to 8\% improved $(\mathrm{P}<0.05)$ their crude fat retention, apparent metabolizable energy, calcium consumption and calcium retention $(\mathrm{P}<0.05)$. In addition, HWM in the ration increased the performance, and also yolk and albumen weight, but decreased $(\mathrm{P}<0.05)$ yolk and albumen index. It can be concluded that HWM improved performance and nutrient retention of quails.
\end{abstract}

Keywords: hatchery waste meal, nutrient retention, performance, quails 


\section{INTRODUCTION}

Poultry hatchery produces large amounts of hatchery waste (Glatz et al., 2011). However, the hatchery waste has not been utilized as poultry feed ingredient, although it contains considerable amount of nutrients and may reduce the feed costs (Abiola et al., 2012; Odunsi et al., 2013). Hatchery waste is usually incinerated, rendered or taken to landfills (Miller, 1984). Moreover, recycling the large quantities of hatchery waste to agricultural lands can pollute the environment, including the ground water (Tymczyna et al., 2000).

Hatchery waste consisted of shells, infertile eggs, unhatched eggs and a viscous liquid from eggs (Glatz et al., 2011). According to Odunsi et al. (2013) it could be classified into whole (as hatched) and shell-less hatchery waste (without shell). These authors (Odunsi et al., 2013) also explained that whole hatchery waste contains higher calcium content than shell-less hatchery waste, while shell-less hatchery waste contains higher protein content than the whole hatchery waste.

Hatchery waste could be processed into a useful feed ingredient in the form of hatchery waste meal (HWM) by cooking, drying and grinding (Odunsi et al., 2013). The use of HWM in the diet is cheaper and advantageous than soybean meal and fish meal (Shahriar et al., 2008). Moreover, the balance of amino acids in HWM is better than that in fish meal (Rasool et al., 1999; Khan and Bhatti, 2002) and other animal feed protein sources (Belewu and Ologunleko, 1995).

Several studies discovered the used of HWM in poultry. Sari (2016) observed that the use of HWM in the ration enhanced calcium intake as well as calcium and protein retention in laying quails. Furthermore, Sathishkumar and Prabakaran (2008) observed the substitution of fish meal with HWM in isoprotein and isocaloric diet up to $100 \%$ (9\% HWM in the diet) without affecting performance of laying quails. Other authors investigated that feeding whole HWM generated a better performance than feeding shellless HWM (Odunsi et al., 2013). In addition, AlHarthi et al. (2010) reported that the use of HWM to replace fish meal up to $100 \%$ level $(10 \%$ HWM in the diet) improved egg quality traits of laying hens aged 25-41 weeks. However, there is scarcity of information concerning of the used of whole and shell-less HWM in relation to nutrient retention, especially in quails. Therefore, the objectives of this study were to investigate the effect of HWM on nutrient retention and performances of laying quails.

\section{MATERIALS AND METHODS}

\section{Preparation of Hatchery Waste Meal}

The quails' hatchery wastes were grouped into whole and shell-less hatchery waste, as described previously, separately boiled at $100^{\circ} \mathrm{C}$ for 15 minutes, then drained for 10-15 minutes, and crushed thereafter. The hatchery wastes then were spread on trays and dried in the oven at $60^{\circ} \mathrm{C}$ for 24 hours (Alaba and Ekeocha, 2012). The collected HWM from several batches were mixed according to the type. The nutrient contents of HWM were analyzed (Association of Official Analytical Chemists-AOAC, 2001) and presented in Table 1.

\section{Animal and Diets}

This study used 500 of 30-days laying quails (Coturnix coturnix japonica) with an average body weight of $94.75 \pm 4.17$ g. They were randomly allocated to 25 pens consisted of five treatments and five replicates each. Each treatment was composed of 20 quails. During adaptation in growing period, the quails were fed a grower diet. The basal diet (Table 2) was fed to laying period quails started from 42 days of age. The dietary treatments were obtained by substitution 4 and $8 \%$ of basal diets with the whole or shell-less HWM (Table 3). The 5 dietary treatments were: 1) Control = basal diet, 2) Whole $4 \%=96 \%$ basal diet $+4 \%$ whole HWM, 3) Whole $8 \%=92 \%$ basal diet $+8 \%$ whole HWM, 4) Shell-less $4 \%=96 \%$ basal diet $+4 \%$ shell-less HWM, and 5) Shell-less $8 \%=92 \%$ basal diet + $8 \%$ shell-less HWM. The dietary treatments were fed for 2 periods of 28 days $(2 \times 28$ days $)$ after the uniform egg production between pens was achieved (50\% egg production).

The performance data collection was performed for $2 \times 28$ days of treatments. Meanwhile, egg quality traits were observed on the last 3 days of each period, using 9 eggs per replicate (total 225 eggs per period) for the measurement of yolk and albumen weight as well as yolk and albumen index. The eggs were cracked and the yolk and albumen heights and diameters were measured using digital micrometer. The yolk and albumen index were calculated according to Rath et al. (2015): 
Table 1. Nutrients Content of Whole and Shell-less Hatchery Waste Meal

\begin{tabular}{lcc}
\hline Nutrient & Whole Hatchery Waste Meal & Shell-less Hatchery Waste Meal \\
\hline Metabolizable energy (kcal/kg) & $\left.3,126.67^{*}\right)$ & $\left.4,076.04^{*}\right)$ \\
Crude protein (\%) & 29.71 & 38.28 \\
Crude fat (\%) & 20.87 & 27.82 \\
Crude fiber (\%) & 4.34 & 3.78 \\
Crude ash (\%) & 38.61 & 25.85 \\
Calcium (\%) & 13.95 & 9.30 \\
Phosphorus (\%) & 0.53 & 0.55 \\
\hline
\end{tabular}

*) Calculated according to Sibbald et al. $(1980)$, metabolizable energy $=3951+(54.4 \times$ crude fat $)-(88.7 \times$ crude fiber $)-(40.8 \times$ crude ash $)$.

Yolk index $(\%)=\frac{\text { Yolk height }(\mathrm{mm})}{\text { Yolk width }(\mathrm{mm})} \times 100$

Albumen index index $(\%)=$

$\frac{\text { Albumen height }(\mathrm{mm})}{\text { Average of albumen length }+ \text { width }(\mathrm{mm})} \times 100$

Nutrient digestibility was measured at the end of the experiment using total excreta collection for 5 days with 4 quails per replicate (total 100 quails) according to the procedure of Ratriyanto et al. (2014). Collected excreta were sun dried and milled thereafter. During the collection period, the eggs were collected to measure the calcium utilization. Determination of crude protein (CP) content of excreta and diet were performed by the Kjeldahl method, while the determination of dry matter (DM), ether extract (EE), crude fiber (CF), and crude ash (CA) were performed according to AOAC (2001). Calcium content of the diet and eggshell were measured by atomic absorption spectrophotometry (AAS). The gross energy of diet and excreta was measured with bomb calorimeter. Nutrient retention ( $g / b i r d)$ was calculated as nutrient intake minus nutrient excreted (Grana et al., 2013). The apparent metabolizable energy (AME, $\mathrm{kcal} / \mathrm{kg}$ ) was calculated as gross energy of feed minus gross energy excreta of the birds (Robbins and Firman, 2006), while calcium utilization was calculated according to Indreswari et al. (2009):

Ca utilization $(\%)=\frac{\text { Ca mass of eggshell }(\mathrm{g})}{\text { Ca intake }(\mathrm{g}) \times \text { Ca digestibility }(\%)} \times 100$
Table 2. Composition of the Basal Diet

\begin{tabular}{lc}
\hline Ingredients & Proportion $(\%)$ \\
\hline Yellow corn & 49.50 \\
Rice bran & 10.12 \\
Wheat bran & 4.27 \\
Soybean meal & 19.00 \\
Fishmeal & 7.18 \\
Coconut oil & 2.00 \\
$D L$-methionine & 0.05 \\
Dicalcium phosphate & 0.86 \\
Limestone & 6.32 \\
Premix & 0.35 \\
$\mathrm{NaCl}$ & 0.35
\end{tabular}

\section{Data Analysis}

The data were analyzed by analysis of variance. If the results of variance analysis showed significant effect, it was then continued by Duncan's Multiple Range Test (Steel and Torrie, 1993).

\section{RESULTS AND DISCUSSION}

\section{Nutrient Retention}

Feeding with HWM increased $(\mathrm{P}<0.05)$ crude fat retention between 8.9 and $51.1 \%$ and apparent metabolizable energy (AME) between 
1.7 and $11.5 \%$ compared with control, without affecting crude protein and dry matter retention (Table 4). Similar to this observation, feeding HWM up to $7.5 \%$ for quails did not affect the digestibility of dry matter and crude protein (Sari, 2016). Grana et al. (2013) observed broiler chickens fed different protein levels concluded, that increasing nitrogen intake was associated with increasing nitrogen excretion, thus, the protein retention was not affected.
The crude fat content in the diets containing HWM was ranged between 3.97 and $5.99 \%$, below maximal requirement of $7 \%$ based on Nutrition Research Council-NRC-(1994), thereby the quails may still increase the crude fat retention. The high fat content in the diet decreased the rate of passage of the digesta, led to enhanced in nutrient digestibility (NRC, 1994). Previous observation in chickens revealed that crude fat retention increased as dietary crude fat

Table 3. Compositions and Nutrients Content of Experimental Diets

\begin{tabular}{lrrrrrrr}
\hline \multirow{2}{*}{ Component } & \multirow{2}{*}{ Control } & \multicolumn{2}{c}{ Whole HWM } & & \multicolumn{2}{c}{ Shell-less HWM } \\
\cline { 7 - 8 } \cline { 6 - 7 } & & $4 \%$ & $8 \%$ & & $4 \%$ & $8 \%$ \\
\hline Basal diet (\%) & 100 & 96 & 92 & & 96 & 92 \\
Whole hatchery waste meal (\%) & 0 & 4 & 8 & & 0 & 0 \\
Shell-less hatchery waste meal (\%) & 0 & 0 & 0 & & 4 & 8 \\
Nutrients content & & & & & & \\
Metabolizable energy (kcal/kg) & 2800.00 & 2814.09 & 2827.95 & & 2854.29 & 2908.16 \\
Crude protein (\%) & 18.00 & 18.50 & 19.00 & & 18.86 & 19.71 \\
Crude fat (\%) & 3.97 & 4.69 & 5.41 & & 4.98 & 5.99 \\
Crude fiber (\%) & 4.97 & 4.94 & 4.92 & & 4.92 & 4.87 \\
Crude ash (\%) & 5.08 & 6.51 & 7.94 & & 5.96 & 6.84 \\
Calcium (\%) & 3.40 & 3.84 & & 4.29 & & 3.65 & 3.89 \\
Available phosphorus (\%) & 0.50 & 0.50 & & 0.51 & & 0.51 & 0.51 \\
\hline
\end{tabular}

HWM: hatchery waste meal

Table 4. Nutrient Retention and Apparent Metabolizable Energy of Quails Fed Hatchery Waste Meal

\begin{tabular}{|c|c|c|c|c|c|}
\hline \multirow{2}{*}{ Variables } & \multirow{2}{*}{ Control } & \multicolumn{2}{|c|}{ Whole HWM } & \multicolumn{2}{|c|}{ Shell-less HWM } \\
\hline & & $4 \%$ & $8 \%$ & $4 \%$ & $8 \%$ \\
\hline $\begin{array}{l}\text { Dry matter retention } \\
\text { (g/day) }\end{array}$ & 16.09 & 15.93 & 15.74 & 16.61 & 17.54 \\
\hline Protein retention (g/day) & 2.26 & 2.00 & 2.36 & 2.25 & 2.22 \\
\hline Fat retention (g/day) & $0.80^{\mathrm{d}}$ & $0.98^{\mathrm{c}}$ & $1.11^{\mathrm{b}}$ & $1.08^{b c}$ & $1.36^{\mathrm{a}}$ \\
\hline AME (kcal/kg) & $2,593.00^{\mathrm{bc}}$ & $2,637.00^{\mathrm{b}}$ & $2,584.00^{\mathrm{c}}$ & $2,892.00^{\mathrm{a}}$ & $2,859.00^{\mathrm{a}}$ \\
\hline
\end{tabular}

a, b, c Mean in the same row with different superscripts are significantly different $(\mathrm{P}<0.05)$

HWM: hatchery waste meal; AME: apparent metabolizable energy 
increased. Furthermore, metabolizable energy was influenced by gross energy content in the diet (Pesti et al., 1986). In support with this finding, Sathishkumar and Prabakaran (2008) observed that metabolizable energy increased as dietary fat increased.

\section{Calcium Utilization}

Feeding with HWM improved $(\mathrm{P}<0.01)$ calcium intake and retention but did not affect $(\mathrm{P}>0.05)$ shell weight and calcium utilization (Table 5). The use of HWM increased calcium intake between 14.4 and $36.6 \%$ due to high calcium content in the diets containing HWM (Table 3), as previously described by Moreki (2005). Feed intake also increased due to the use of HWM, resulting in higher calcium intake (Table 4). Calcium content in shell-less HWM $(9.30 \%)$ was lower than those in whole HWM $(13.95 \%)$ since shell-less HWM contained no shell, a source of calcium in HWM (Odunsi et al., 2013). In accordance with this result, inclusion of HWM in the diets increased the calcium content, led to an increase in calcium intakes (Vandepopuliere et al., 1977). In addition, improvement in egg production and egg weight in this study increased calcium requirements for egg formation, resulting an increased in calcium intake (Wahju, 2004).

The use of HWM enhanced calcium retention by 9.2 to $31.7 \%$, associated with enhanced in egg production and egg weight which required calcium for eggshell formation (Wahju, 2004). In agreement with this study, Underwood and Suttle (1999) stated that calcium was absorbed based on the requirements. Improvement in calcium intake and retention did not affect eggshell weight since calcium deposition was maintained to be constant (Lichovnicova, 2007; Vieira et al., 2011). The unused calcium for egg formation was deposited in bone (Bar, 2008), or excreted through excreta (Wahju, 2004). Previous study has shown that increasing dietary calcium levels in the diet from 3.75 to $4.55 \%$ did not affect the eggshell weight of chickens (Murata et al., 2009).

The calcium utilization was not affected by the use of HWM in the diets, which appeared by the constant eggshell weight, indicating that the calcium deposition in eggshell was maintained to be constant (Lichovnicova, 2007; Vieira et al., 2011). Calcium absorption was determined by calcium requirement (Underwood and Suttle, 1999). Furthermore, the ratio of calcium:phosphorus in this study ranged between 6.80 and 8.60. According to Pelicia et al. (2009) calcium:phosphorus ratio between 7.50 and 18.00 in the diets did not affect the eggshell weight in laying hens.

\section{Productive Performance}

Feeding with HWM increased $(\mathrm{P}<0.05)$ feed intake, egg production and egg weight (Table 6). Feeding whole and shell-less HWM increased feed intake between 5.9 and $7.0 \%$, respectively. Protein in HWM has a high biological value and digestibility and a good amino acid balance, led to increase in feed intake (Lilburn et al., 1997; Khan and Bhatti, 2002). The increase in feed intake was correlated with increasing egg production (5.8$24.3 \%)$ and egg weight (6.7-10.6\%) in this study. The improvements in egg production and egg weight require more nutrients such as energy and protein which were fulfilled from the diets, led to higher feed intake due to the use of HWM in the ration. Improvement in performance of the birds could be explained due to higher nutrient available such as energy and protein (Shanaway, 1994).

The development of follicles in the ovary is affected by the availability of nutrients (Yoshida et al., 2011). The diets containing HWM have higher nutrient contents than the diet without HWM as indicated by the higher fat retention and AME (Table 4), thus, there were more available nutrients can be used for follicular development as indicated by higher egg production (Sakomura, 2004).

The higher fat retention in this study, associated with higher fatty acids retention, promoted the synthesis of cholesterol as a precursor of reproductive hormones (Peebles et al., 1998; Mumford et al. 2016) led to higher egg production in this study. Essential fatty acids act as precursor for long-chain derivatives which were used in cell membrane and for synthesis of hormone-like substrates involved in reproduction (Purdum and Didde, 2012). Previous observation showed that fatty acids enhanced the reproductive performance in chicken by increasing hormone secretion and function, and latter by up-regulating receptor expression (Feng et al., 2015). It is generally accepted that high-fat diets increased the concentration of estrogens in the blood. Estrogen involved in the regulation of calcium metabolism, along with vitamin D3 and calcium binding protein. Estrogen also stimulates the synthesis of calcium binding proteins, which 
Table 5. Calcium Utilization of Quails Fed Hatchery Waste Meal

\begin{tabular}{lccccccc}
\hline \multirow{2}{*}{ Variables } & \multirow{2}{*}{ Control } & \multicolumn{2}{c}{ Whole HWM } & & \multicolumn{2}{c}{ Shell-less HWM } \\
\cline { 3 - 4 } \cline { 6 - 7 } & & $4 \%$ & $8 \%$ & & $4 \%$ & $8 \%$ \\
\hline Ca intake (g/day) & $1.53^{\mathrm{c}}$ & & $1.80^{\mathrm{b}}$ & $2.09^{\mathrm{a}}$ & & $1.75^{\mathrm{b}}$ & $2.02^{\mathrm{a}}$ \\
Ca retention (g/day) & $1.20^{\mathrm{c}}$ & $1.38^{\mathrm{b}}$ & $1.58^{\mathrm{a}}$ & & $1.31^{\mathrm{bc}}$ & $1.43^{\mathrm{ab}}$ \\
Eggshell weight (g) & 0.88 & & 0.87 & 0.95 & & 0.96 & 0.97 \\
Ca utilization (\%) & 21.40 & 18.11 & 16.78 & & 19.83 & 19.37 \\
\hline
\end{tabular}

a, b, c Mean in the same row with different superscripts are significantly different $(\mathrm{P}<0.05)$

HWM: hatchery waste meal

Table 6. Performance of Quails Fed Hatchery Waste Meal

\begin{tabular}{|c|c|c|c|c|c|}
\hline \multirow{2}{*}{ Variables } & \multirow{2}{*}{ Control } & \multicolumn{2}{|c|}{ Whole HWM } & \multicolumn{2}{|c|}{ Shell-less HWM } \\
\hline & & $4 \%$ & $8 \%$ & $4 \%$ & $8 \%$ \\
\hline Feed intake (g/day) & $25.35^{\mathrm{b}}$ & $26.85^{\mathrm{a}}$ & $27.06^{\mathrm{a}}$ & $27.00^{\mathrm{a}}$ & $27.12^{\mathrm{a}}$ \\
\hline Egg production (\%) & $66.17^{b}$ & $69.99^{\mathrm{b}}$ & $77.64^{\mathrm{a}}$ & $78.86^{\mathrm{a}}$ & $82.25^{\mathrm{a}}$ \\
\hline Egg weight (g) & $9.41^{\mathrm{c}}$ & $10.04^{\mathrm{b}}$ & $10.16^{\mathrm{ab}}$ & $10.25^{\mathrm{ab}}$ & $10.41^{\mathrm{a}}$ \\
\hline Feed conversion ratio & $4.28^{\mathrm{a}}$ & $4.00^{\mathrm{a}}$ & $3.48^{\mathrm{b}}$ & $3.45^{\mathrm{b}}$ & $3.23^{\mathrm{b}}$ \\
\hline
\end{tabular}

a, b, c Mean in the same row with different superscripts were significantly different $(\mathrm{P}<0.05)$

HWM: hatchery waste meal

facilitates the calcium transportation for eggshell formation (Darre, 2011).

The solid yolk is composed of lipoproteins (Yoshinori and Yang, 2010), thus, high levels of energy, protein and fat in the diets containing HWM increased egg weight. Furthermore, as a consequence of the improvement in egg production and egg weight, feeding with HWM improved feed conversion ratio ranged from 6.5 to $24.5 \%(\mathrm{P}<0.05)$. The lower feed conversion ratio indicated better utilization of nutrients (Ratriyanto et al., 2017).

\section{Egg Quality Traits}

The use of HWM in the diets increased $(\mathrm{P}<0.05)$ yolk and albumen weight but decreased $(\mathrm{P}<0.05)$ yolk and albumen index (Table 7). Feeding with both whole and shell-less HWM increased the yolk weight by $92.2-15.6 \%$, which was associated with an increase in fat retention (Table 4), providing more fats available for the yolk formation. Different from this study, Mahmud et al. (2015) reported that feeding with HWM for laying hens up to $12 \%$ did not increase yolk weight.

Feeding with whole and shell-less HWM increased albumen weight between 6.1 and $10.0 \%$ (Table 7). Provision of HWM might increase protein availability to form albumen. Although the administration of HWM did not affect $(\mathrm{P}>0.05)$ crude protein retention (Table 4), but HWM has a high biological value (Lilburn et al., 1997) and a good amino acids balance (Rasool et al., 1999; Khan and Bhatti, 2002), providing more protein available for albumen formation. Previous observation showed that feeding with whole HWM up to $12 \%$ increased albumen weight in laying hens (Mahmud et al., 2015).

The quails fed HWM resulted in a lower yolk and albumen index $(\mathrm{P}<0.05)$ than the those fed without HWM, despite of a small magnitude (Table 7). The use of HWM increased the fat 
Table7. Egg Quality Traits of Quails Fed Hatchery Waste Meal

\begin{tabular}{|c|c|c|c|c|c|}
\hline \multirow{2}{*}{ Variables } & \multirow{2}{*}{ Control } & \multicolumn{2}{|c|}{ Whole HWM } & \multicolumn{2}{|c|}{ Shell-less HWM } \\
\hline & & $4 \%$ & $8 \%$ & $4 \%$ & $8 \%$ \\
\hline Yolk weight (g) & $2.83^{\mathrm{c}}$ & $3.09^{b}$ & $3.16^{\mathrm{ab}}$ & $3.11^{\mathrm{b}}$ & $3.27^{\mathrm{a}}$ \\
\hline Albumen weight (g) & $5.90^{\mathrm{b}}$ & $6.26^{\mathrm{a}}$ & $6.42^{\mathrm{a}}$ & $6.35^{\mathrm{a}}$ & $6.49^{\mathrm{a}}$ \\
\hline Yolk index & $0.530^{\mathrm{a}}$ & $0.516^{\mathrm{b}}$ & $0.518^{\mathrm{b}}$ & $0.524^{b}$ & $0.514^{\mathrm{b}}$ \\
\hline Albumen index & $0.158^{\mathrm{a}}$ & $0.154^{\mathrm{ab}}$ & $0.146^{\mathrm{c}}$ & $0.156^{\mathrm{ab}}$ & $0.150^{\mathrm{bc}}$ \\
\hline
\end{tabular}

a, b, c Mean in the same row with different superscripts are significantly different $(\mathrm{P}<0.05)$

HWM: hatchery waste meal

content in the diet (Odunsi et al., 2013) and increased fat retention (Table 4) which can be utilized as yolk precursor and manifested by increased in yolk diameter, resulting a decrease in yolk index. Similarly, the high biological value of HWM might improve the protein available for albumen formation (Lilburn et al., 1997) and manifested in the increase of albumen diameter, resulting in a lower albumen index. Observation in quails showed that feeding $9.67 \% \mathrm{HWM}$ in isoprotein diets generated an equal yolk index as compared to quails fed 5\% HWM (Odunsi et al., 2013). In addition, Mahmud et al. (2015) reported that feeding $12 \%$ HWM in laying hens did not affect the yolk index.

\section{CONCLUSION}

The findings of this study suggest that the use of whole and shell-less hatchery waste meal improved nutrient retention, which associated with the improvement in quails' performances. Hence, hatchery waste meal could be used as a feed ingredient in quail diet up to $8 \%$ to maintain reasonably good production without unfavorable effects on egg quality.

\section{ACKNOWLEDGMENTS}

The financial support from the PNBP Research Grant 2016 of Sebelas Maret University with contract number $623 / \mathrm{UN} 27.21 / \mathrm{PP} / 2017$ is gratefully acknowledged.

\section{REFERENCES}

Abiola, S.S., N.E. Radebe, C.V.D. Westhuizen and D.O. Umesiobi. 2012. Whole hatchery waste meal as alternative protein and calcium sources in broiler diets. Arch. Zootec. 61:229-234.

Alaba, O. and A.H. Ekeocha. 2012. Replacement value of fishmeal by poultry hatchery waste meal in the diets of pullet growers and layers. Sci. J. Anim. Sci. 1:7-13.

Al-Harthi, M.A., A.A. El-Deek, M.S. El-Din and A.A. Alabdeen. 2010. A nutritional evaluation of hatchery by-product in the diets for laying hens. Egypt. Poult. Sci. J. 30:339-351.

AOAC. 2001. Official Methods of Analysis of the Association of Official Analytical Chemists. Washington, D.C.

Bar, A. 2008. Calcium homeostasis and vitamin D metabolism and expression in strongly calcifying laying birds. Comp. Biochem. Physiol. Part A. 151:477-490.

Belewu, M.A. and A.A Ologunleko. 1995. Digestibility and nitrogen utilization hatchery by-product as a source of protein for west African dwarf goats. Nig. J. Pure Appl. Sci. 11:392-393.

Purdum, S.E. and D. Didde. 2012. Fats and fatty acids in laying hens. In: Fats and Fatty Acids in Poultry Nutrition and Health Infection (Cherian, G. and R. Poureslami, eds). Context Products, Leicestershire, UK. P. 1-6.

Darre, J.M. 2011. Poultry Biology. College of Agriculture and Natural Resources University of Connecticut. Connecticut.

Feng, Y., Y. Ding, J. Liu, Y. Tian, Y. Yang, S. Guan and C. Zhang. 2015. Effects of dietary omega-3/omega-6 fatty acid ratios on reproduction in the young breeder rooster. BMC Vet. Res. 11:73. 
Glatz, P., Z. Miao and B. Rodda. 2011. Handling and treatment of poultry hatchery waste: a review. Sustainability. 3: 216-237.

Grana, A.L., F.C. Tavernari, L.F.T Albino, H.S. Rostagno and P.C. Gomes. 2013. Evaluation of nutrient excretion and retention in broiler submitted to different nutritional strategies. Rev. Bras. Cienc. Avic. 2:161-168.

Indreswari, R., H.I. Wahyuni, N. Suthama and P.W. Ristiana. 2009. Pemanfaatan kalsium untuk pembentukan cangkang telur akibat perbedaan porsi pemberian ransum pagi dan siang pada ayam telur. J. Indon. Trop. Anim. Agric. 34:134-138.

Khan, S.H. and B.M. Bhatti. 2002. Effect of feeding cooked hatchery waste on the performance of broilers. Pak. Vet. J. 22(1):27-30.

Lichovnicova, M. 2007. The effect of dietary calcium source, concentration and particle size on calcium retention, eggshell quality and overall calcium requirement in laying hens. Br. Poutr. Sci. 48:71-75.

Lilburn, M.S., G.W. Barbour, R. Nemasetoni, C. Coy, M. Werling and A.G. Yersin. 1997. Protein quality and calcium availability from extruded and autoclaved turkey hatchery residue. Poult. Sci.76:841-848.

Mahmud. A., Saima, M.A. Jabbar, A.W. Sahota, Z. Hayat and M.Z.U. Khan. 2015. Effect of feeding hatchery waste meal processed by different techniques on egg quality and production performance of laying hens. Pak. J. Zool. 47(4):1059-1066.

Miller, B.F. 1984. Extruding hatchery waste. Poult. Sci. 63:1284-1286.

Moreki, J. C. 2005. The Influence of Calcium Intake by Broiler Breeders on Bone Development and Egg Characteristics. Ph.D Thesis. University of the Free State, Bloemfontein, Republic of South Africa.

Mumford, S.L., J.E. Chavarro, C. Zhang, N.J. Perkins, L.A. Sjaarda, A.Z. Pollack, K.C. Schliep, K.A. Michels, S.M. Zarek, T.C. Plowden, R.G. Radin, L.C. Messer, R.A. Frankel and J. Wactawski-Wende. 2016. Dietary fat intake and reproductive hormone concentrations and ovulation in regularly menstruating women. Am. J. Clin. Nutr. 103:868-877.

Murata, L.S., J. Ariki, A.P. Santana and F.R.M. Jardim. 2009. Calico and levels particle size of limestone on the performance and egg shell quality of laying hens commercials.
Biotem. Mag. 22:103-110.

National Research Council. 1994. Nutrient Requirement of Poultry. 9th Rev. Ed. National Academic Press, Washington DC.

Odunsi, A.A., A.O. Akinwumi and O.I. Falana. 2013. Replacement value of hatchery waste meal for fish meal in the diet of laying Japanese quail (Coturnix coturnix japonica). Int. Food Res. J. 20:3107-3110.

Peebles, E.D., T. Pansky, S.M. Doyle, T.W. Smith, C.R. Boyle, M.A. Latour and P.D. Gerard, 1998. Effects of breeder dietary fat and eggshell cuticle removal on subsequent broiler growout performance. J. Appl. Poultry Res. 7:377-383.

Pelicia, K., E.A. Garcia, A.B.G. Faitarone, A.P. Silva, D.A. Berto, A.B. Molino and F. Vercese. 2009. Calcium and available phosphorus levels for laying hens in second production cycle. Rev. Bras. Cienc. Avic. 11:39-49.

Pesti, G.M, L.O. Faust, H.L. Fuller and N.M. Dale. 1986. Nutritive value of poultry by product meal. I. Metabolizable energy values as influenced by method of determination and level of substitution. Poult Sci. 65:2258-2267.

Rasool, S., M. Rehan, A. Haq and M.Z. Alam. 1999. Preparation and nutritional evaluation of hatchery waste meal for broilers. AsianAust. J. Anim. Sci. 12:554-557.

Rath, K.R., P.K. Mishra, B.K. Mallick and N.C. Behura. 2015. Evaluation of different egg quality traits and interpretation of their mode of inheritance in White Leghorns. Vet. World. 8: 449-452.

Ratriyanto, A., R. Indreswari and A.M.P. Nuhriawangsa. 2017. Effects of dietary protein level and betaine supplementation on nutrient digestibility and performance of Japanese quails. Rev. Bras. Cienc. Avic. 19:445-454.

Ratriyanto, A., R. Indreswari and Sunarto. 2014. Effects of protein levels and supplementation of methyl group donor on nutrient digestibility and performance of broiler chickens in the tropics. Int. J. Poult. Sci. 13:575-581.

Robbins, D.H. and J.D. Firman. 2006. Evaluation of the metabolizable energy of poultry byproduct meal for chickens and turkeys by various methods. Int. J. Poult. Sci. 5:753758.

Sakomura, N.K. 2004. Modeling energy 
utilization in broiler breeders, laying hens and broiler. Rev. Bras. Cienc. Avic. 6:1-11.

Sari, T.M.P. 2016. Kecernaan Nutrien dan Energi Metabolis Puyuh (Coturnix coturnix japonica) yang Diberi Tepung Limbah Penetasan dalam Ransum. Bachelor Thesis. Faculty of Agriculture. Sebelas Maret University, Surakarta.

Sathishkumar, A. and R. Prabakaran. 2008. Recycling of Japanese quail hatchery waste on egg production performance of quail breeders. J. Vet. Anim. Sci. 4:123-128.

Shahriar, H.A, K. Nazer-Adl, J. Doolgarisharaf and H. Monirifar. 2008. Effect of dietary different levels of hatchery waste in broiler. J. Anim. Vet. Adv. 7:100-105.

Shanaway, M.M. 1994. Quail Production Systems: A Review. Food and Agriculture Organization, Rome.

Sibbald, I.R., K. Price and J.P. Barrette. 1980. True metabolizable energy values for poultry of commercial diet measured by bioassay and predicted from chemical data. Poult Sci. 59:08-11.

Steel, R.G. and J.H. Torrie. 1993. Prinsip dan Prosedur Statistika. Gramedia Pustaka Utama, Jakarta.

Tymczyna, L., A. Chmielowiec-Korzeniowska and L. Saba. 2000. Effect of a pig farm on the physical and chemical properties of a river and ground water. Polish J. Environ.
Stud. 9:97-102.

Underwood, E.J. and N.F. Suttle. 1999. The Mineral Nutrition of Livestock, 3rd ed. CABI Publishing, United Kingdom.

Vandepopuliere, J.M., H.K. Kanungo, H.V. Walton and O.J. Cotterill. 1977. Broiler and egg type chick hatchery by-product meal evaluated as laying hen feedstuffs. Poult. Sci. 56:1140-1144.

Vieira, M.M., A.M. Kessler, A.M.L. Ribeiro, I.C.M. Silva and M.A. Kunrath. 2011. Nutrient balance of layers fed diets with different calcium levels and the inclusion of phytase and/or sodium butyrate. Rev. Bras. Cienc. Avic. 13:157-162.

Wahju, J. 2004. Ilmu Nutrisi Unggas. Gadjah Mada University Press, Yogyakarta.

Yoshida, N., M. Fujita, M. Nakahara, T. Kuwahara, S. Kawakami and T. Bungo. 2011. Effect of high environmental temperature on egg production, serum lipoproteins and follicle hormones in laying hens. J. Poult. Sci. 48:207-211.

Yoshinori M. and M. Yang. 2010. Functional properties of egg components in food systems. In: Handbook of Poultry Science and Technology Volume 1: Primary Processing (I. Guerrero-Legarreta, ed). John Wiley \& Sons, Inc., Hoboken, New Jersey, P. 579-630. 